\title{
Can the international human rights framework improve the rights of Indigenous Australians?
}

\author{
Christina Crawford
}

\begin{abstract}
This paper explores the possibilities and limitations that the international human rights framework offers for progressing the rights of Indigenous Australians.
\end{abstract}

Keywords: human rights; Indigenous Australians; Declaration on the Rights of Indigenous Peoples

The United Nations aims to provide global standards for the treatment and protection of both individual and collective rights. The Declaration on the Rights of Indigenous People formed a universal framework defining the minimum standards for treatment of Indigenous peoples. It is however, Australia's role to ensure that these standards are met on a national level, and therefore the success of the declaration is dependent on the State's commitment to comply with international law.

Although the Universal Declaration of Human Rights was adopted in 1948, it focused on the rights of the individual and therefore failed to consider the rights of marginised collective groups, such as Indigenous people. After a global shift in the recognition of a need to protect and preserve Indigenous cultures, the United Nations declared 1993 the Year of the World's Indigenous Peoples, and aimed to combat racism and discrimination against traditional cultural groups, as a reflection of the United Nation's anti-colonial consciousness (Stamatopoulou, 1994). This movement came as Indigenous people refused to continue to be "objects of the discussion of their rights" and instead demanded "real participation in the multilateral dialogue" (Stewart, 2006). In 2007, the UN Declaration on the Rights of Indigenous Peoples was finally adopted by the General Assembly, after more than twenty years of discussion on the topic. It was voted in by majority, with 143 states in favor of the proposal, however, not so surprisingly the four countries that voted against the declaration were Australia, Canada, New Zealand and the United States. The Declaration 
established a universal framework outlining the minimum standards for treatment of Indigenous peoples, focusing on their rights to recognition, survival, dignity and fair treatment. The Declaration addresses both individual and collective rights; rights around identity, culture and language; the right to have access to education, health and employment, as well as many others. It prohibits discrimination against indigenous peoples and promotes their participation in all matters that concern them as a collective. It also upholds their rights as individuals to pursue their own priorities in economic, social and cultural development. Finally, the Declaration directly encourages positive and cooperative relationships between the State and its Indigenous peoples (UNDRIP, 2008).

Although nations are morally and ethically bound to their agreements, the technically unbinding nature of international law, being 'soft law', means that international legal frameworks cannot be enforced within sovereign states until the federal government ratifies the convention and enacts their own legislation. Roberts questions whether international law constitutes 'law' at all, and rather considers it a set of moral standards to be globally upheld (Roberts, 2004). If a country fails to comply with their signatory responsibilities they cannot be directly prosecuted, however, actions such as sanctions and exclusion from political and economic gain can be used to encourage nations to comply (Cawthray, 2013). The Australian government announced its support for the Declaration on the Rights of Indigenous People on the $3^{\text {rd }}$ of April 2009, two years after the General Assembly adopted the framework. This delayed step came along with the Labor Government's National Apology to Australia's Indigenous Peoples, in particular, the Stolen Generations. The announcement demonstrated the Government's first commitment to strengthen the relationship between the State and Indigenous Australians (Sovereign Union, 2012). However, being a signatory to the international rights declaration did not make the standards within the convention legally enforceable within Australia. Without the supporting federal legislation, there is no legal way within the Australian court system to ensure that the international human rights agreement will take precedence over any state's legislation.

When Australia's Constitution was first formed, the adoption of a Bill of Rights, along the lines of that in the Unites States, was debated, however the proposal was defeated and still to this day our Constitution contains few protections for globally recognised human rights. Australia signed the Universal Declaration on Human Rights in 1948, and while legislation such as the AntiDiscrimination Act, and constitution rights such as the right to vote, aim to protect the rights of the individual, Australia is still being urged by International rights monitors to improve and 'rethink the implementation' of human rights (Australian Human Rights Commission, 2006). Williams notes that Australia's failure to uphold these standards is far worse than John Howard's statement "we've had our blemishes and we've made our errors", and in reality reflects an ongoing weakness in our democratic system as the nation falls far behind standards upheld by nations such as Canada and New Zealand (Williams, 2007). After Signing the Declaration on the rights of Indigenous Peoples in 2009, Australia has made few enactments to reflect any attempt to ratify this declaration in Australian law. Article 1 of the Declaration on the Right of Indigenous Peoples states, "Indigenous peoples have the right to the full enjoyment, as a collective or as individuals, of all human rights and fundamental freedoms as recognized in the Charter of the United Nations, the Universal Declaration of Human Rights and international human rights law" (DRIP). Australia's inability to fully protect these rights is therefore a failure to meet international law standards across multiple Declarations. 
The Australian Constitution was passed by the British Parliament as part of the Commonwealth of Australia Constitution Act 1900 and took effect on $1^{\text {st }}$ of January 1901. The Constitution is the founding document and legal framework for the way in which Australia is governed. It aims to protect and reflect Australian values in a formal and absolute structure. However, the document is undeniably outdated, as the binding nature of the constitution limits its ability to adapt to societal progress. Indicative of the British views at the time, the constitution made no mention of Aboriginal and Torres Strait Islander people. The 1967 referendum was however, the first step in which Australians voted YES to giving the federal parliament the power to make laws in relation to Aboriginal and Torres Strait Islander people, and included them in the census for the first time. However, this amendment did very little in attempting to improve the quality of life for Indigenous Australians (Recognise, 2017). It did not recognise Aboriginal and Torres Strait Islander peoples as the first of this nation, neither did it remove the clauses allowing the government to form 'special laws' and disqualify racial groups from voting. The fact that the Constitution still allows racial discrimination, not only against Indigenous people but against anyone based on their race, is a clear reflection of Australia's inability to meet global human rights standards. A succinct and binding way in which Australia could meet these standards is to amend its most formal document, the Constitution. Recognising Aboriginal and Torres Strait Islander people as the first Australians in the Constitution and ensuring the Constitution does not discriminate against race would be a huge step towards improving Australia's relationship between indigenous and non-indigenous Australians. Recognising Aboriginal People as the first Australians would not give then more rights than others, but rather build stronger relationships of trust and mutual respect first the traditional custodians of our nation.

Article 2 of the Declaration states that "Indigenous peoples and individuals are free and equal to all other peoples and individuals and have the right to be free from any kind of discrimination, in the exercise of their rights, in particular that based on their indigenous origin or identity" (DRIP). Australian law conveys conflicting attempts to ratify this agreement, as an inconsistency across legislative and constitutional law can lead to flawed Common Law interpretations (Rule of Law.org). As mentioned prior, Section 51 of the Australian Constitution allows laws to be made based upon a person's race, and section 25 allows the state to disqualify people on the basis of their race. In contrast, the Racial Discrimination Act outlaws this behaviour. This inconsistency in policy is a reflection of Australia's weak democratic structure, as the legal system so often fails to protect Australians from the violation of their fundamental rights (Williams, 2007). The inhuman detention of children in Australia breaches several international treaties. Australia's mandatory sentencing policy was put in place in 1997, in the Northern Territory, and led to an alarming rise in imprisonment of Indigenous people, including women and children. When the regime was questioned in the Supreme Court, the absence of a charter of rights meant that there was no principle that could be used to defeat the mandatory sentencing policy, despite its severe impact on Indigenous Australians, as well as its breach of the Convention on the Rights of the Child, Universal Declaration of Human Rights and Declaration on the Rights of Indigenous People. Although the United Nations Committee on the Elimination of Racial Discrimination found that the policy had a "racially discriminatory impact" there was no legislation to force Australia to comply, indicating that the Declaration on Human Rights failed to protect Indigenous Peoples (Williams, 2007). 2001 fortunately saw a repeal of the policy under the federal Labor government, however this was due to a change in government policy, rather than a duty to comply with International law. 
Articles 10, 25, 26, 28 and 29 all refer to Indigenous peoples' right to land and protection of the environment, considering traditional and spiritual connections. Article 26 states that

Indigenous peoples have the right to the lands, territories and resources which they have traditionally owned, occupied or otherwise used or acquired.

2. Indigenous peoples have the right to own, use, develop and control the lands, territories and resources that they possess by reason of traditional ownership or other traditional occupation or use, as well as those which they have otherwise acquired.

3. States shall give legal recognition and protection to these lands, territories and resources. Such recognition shall be conducted with due respect to the customs, traditions and land tenure systems of the indigenous peoples concerned.

(DRIP, 2007)

Australia's Native Title Act was passed by the Australian Parliament in 1993, after the Mabo decision in 1992 set precedence for making native title claims. The Australian courts ruled that traditional law and customs could be a basis for claiming land ownership by Indigenous People. Codifying the Mabo decision, the Act formed a national system for recognition and protection of native title. While this piece of legislation is a positive example of Australia implementing the globally recognised right for Indigenous People, it is important to note claims can only be made for certain parts of the country that are unallocated or vacant Crown land, and the claims have to prove a continuity of traditional laws and customs on the land being claimed. This process often involves ongoing research and clear evidence from living descendants (Mara, 2014). A successful claim does not necessarily give Indigenous parties exclusive access to the land, and in many cases they will only have the right to live on the area or use it for ceremonies. While this meets Article 25's right to "maintain and strengthen their distinctive spiritual relationship with their traditional owned lands", it does not meet Article 26's right to "control and develop" the land.

Article 29 states that "Indigenous peoples have the right to the conservation and protection of the environment and the productive capacity of their lands or territories and resources" (DRIP). Australia is constantly in breach of this framework. With a strong history of mining and farming, the Australian landscape has in many cases been used for both state and individual capital gain, without compensation or permission from Indigenous Peoples. This is an example of Australia's inability to recognise Indigenous peoples international right to both protect traditional lands and develop their own economic growth. A current example of this failure to protect Indigenous land is Adarni's Carmichael Coal Mine in Queensland's Galilee Basin. The Wangan and Jagalingou people are the Traditional Owners of the land and are in grave fear of the devastating impacts on their native title and ancestral lands. The group have stated that "If the Carmichael mine were to proceed it would tear the heart out of the land" while also recognising its contributions to the broader issue of climate change (Wangan \& Jagaligou Family Council, 2017). Cases like this depict Australia's policies of economic gain prioritised over the rights of Indigenous People.

Unfortunately, Australia has made few enactments that reflect any attempt to ratify the Declaration on the Rights of Indigenous Peoples. With failures to ratify and inconsistencies in legislation, it is clear that international law has generally failed to progress and improve rights upheld in Australia. The clearest way Australia could improve these standards would be to amend its most formal 
document, the Constitution. Recognising Aboriginal and Torres Strait Islander people as the first Australians and ensuring the Constitution does not discriminate against anyone based upon their race would be a huge step towards improving the relationship between indigenous and nonindigenous Australians, while improvements to land rights and Native Title would reflect the State's attempt to compensate and respect Indigenous connections to the land.

\section{References}

Australians Together, United Nation Declaration on the Rights of Indigenous People, viewed on the $14^{\text {th }}$ June 2017 http://www.australianstogether.org.au/stories/detail/international-declaration-on-therights-of-indigenous-peoples

Australian Human Right Commission, 2017, About Constitutional Change, viewed on the $9^{\text {th }}$ June https://www.humanrights.gov.au/publications/about-constitutional-recognition

Australian Human Right Commission, 2006, How Are Human Rights Protected in Australian Law, viewed on the $14^{\text {th }}$ June, https://www.humanrights.gov.au/how-are-human-rights-protectedaustralian-law

Aboriginal and Torres Strait Islander Peoples Recognition Act 2013, https://online.uts.edu.au/bbcswebdav/pid-2156596-dt-content-rid-9571017_1/courses/54085-2017AUTUMN-CITY/A\%26TSI\%20Peoples\%20Recognition\%20Act.pdf

Cawthray, T. 2013, Updating International Law Enforcement Ethic: International Code of Conduct, Criminal Justice Ethics Journal, New York https://doi.org/10.1080/0731129X.2013.860728

Darren Mara, 2014, Native Title Act -20 years on, viewed on $14^{\text {th }}$ June, SBS News, http://www.sbs.com.au/news/article/2014/02/28/native-title-act-20-years

Malezer, L. 2010, International Representation, Australian Institute of Aboriginal and Torres Strait Islander Studies.

Recognise Organisation, 2017, Stand for Recognition, viewed on the $9^{\text {th }}$ June http://www.recognise.org.au/

Robert, E. 2004, Self-Enforcing International Agreements and the Limits of Coercion, New York

Stamatopoulou, E. 1994, Indigenous Peoples and the United Nations: Indigenous People as a Developing Dynamic, Human Rights Quarterly.

Stewart, S. 2006, Application of International Law to the Problems of Indigenous Peoples: The Indigenous Rights Movement in Other Contexts, Sydney

United Nations Declaration on the Right of Indigenous People, 2008. 
Williams, G. 2007, A Charter of Rights for Australia, 3rd ed., University of New South Wales Press, Sydney.

Wangan \& Jagalingou Family Council, 2017, Stop Adani Destroying Our Land and Culture, viewed on $15^{\text {th }}$ June, http://wanganjagalingou.com.au/our-fight/

(C) 2018 by the author. This article is distributed under the terms and conditions of the Creative Commons Attribution license (http://creativecommons.org/licenses/by-nd/4.0/). 